\title{
Allen Ginsberg and China
}

\author{
$\mathrm{Min} \mathrm{Yu}$ \\ Huaiyin Institute of Technology, Huai'an, China \\ Email: huboemail@126.com
}

\begin{abstract}
After the Second World War, because of their dissatisfaction of the extreme materialism and industrialization and the indifference of the government, some American poets of the Beat Generation turned to the East, especially turning to China to learn the classical Chinese poetry and the philosophy of Lao Tzu and Chuang Tzu implied in the poetry, which advocates the harmonious relationship of human beings and the universe, and incorporated what they learned in their own poetry to stress humanity and harmony between man and nature. Allen Ginsberg is one of the most revered Beat poets. He is quite familiar with Chinese culture and has assimilated its essence into his own poems. Ginsberg not only uses the Chinese-style approach of image juxtaposition but exaggerates it to the most so as to express his indignation to the dirty society to his heart's content. The power of meditation of Buddhism and Ch'an has also transformed Ginsberg's poems from the angry "Howl" to the calm and tolerant "Wichita Vortex Sutra", and helped him reach the "beatific" spiritual realm.
\end{abstract}

Index Terms - classical Chinese poetry, the Beat Generation, Allen Ginsberg

\section{INTRODUCTION}

Allen Ginsberg is one of the most respected and revered Beat writers. His works are definitely worth reading and worth researching as well even if the writers of this period are of little interest to certain readers.

Ginsberg was born in 1926 in Newark, New Jersey and received his B.A. from Columbia University in 1948. His father, Louis Ginsberg, was a socialist, but his mother, Naomi, belonged to the Communist Party. The long poem "Kaddish" expresses Ginsberg's deep affection to his mother and fury to the evil government which is responsible to Naomi's insaneness and death. Like Kenneth Rexroth and Gary Snyder, Ginsberg held a variety of odd jobs before becoming an established writer. He worked on various cargo ships, a spot welder, a dishwasher and he also worked as a night porter in Denver. He participated in numerous poetry readings, including the famous Six Gallery event that occurred in San Francisco.

In addition to the almost epic poem "Howl", Ginsberg has authored numerous books. Many of his writings were once interpreted as controversial and even obscene. The reading of "Howl" resulted in the arrest of Lawrence Ferlinghetti, the owner of City Lights Books, on obscenity charges. The authorities were angered by Ginsberg's openness towards his homosexuality as well as his graphic sexual language. Many of his other writings deal with subjects such as narcotics and his own experiences with them. However, many other prominent writers, including Jack Keroauc, William Carlos Williams, Kenneth Rexroth and Gary Snyder realized Ginsberg's importance. Ginsberg was greatly influenced by Kerouac and William Burroughs's spontaneous and carefree style and often worked in a stream of consciousness manner until he completed a work. Ginsberg was compared with the metaphysical poets, including William Blake, Thoreau, Emerson and Whitman. In addition to the greatest influence of William Carlos Williams (who respects Chinese culture too), Ginsberg's poetics and poems were also influenced by classical Chinese poems and thoughts.

In the early period of Ginsberg's writing, it was the desire to expand the mind and reach the spiritual that inspired Ginsberg to experiment with substances such as marijuana and Benzedrine. He claimed that many of his writings, including "Howl" were written while he was under the influence of drugs. Latter, under the influence of Ezra Pound, Kenneth Rexroth and Gary Snyder, he turned to the Eastern world, found his spiritual home in Buddhism, in Chinese Ch'an and Chinese poetics. As to how great the influence is, his own words in the poem "Improvisation in Beijing" written in China are most convincible:

I write poetry because Pound pointed young Western poets to look at Chinese writing word pictures.

$\cdots$

I write poetry because young friend Gary Snyder sat to look at his thoughts as part of external phenomenal world just like a 1984 conference table.

I write poetry because this morning I woke trembling with fear what could I say in China?

$\ldots$

I write poetry because Chuang -tzu couldn't tell whether he was butterfly or man, Lao-tzu said water flows downhill, Confucius said honor elders, I wanted to honor Whitman.

...

I write poetry because the Tibetan Lama guru says, “Things are symbols of themselves.” (Ginsberg, 2001, p.204-207) 


\section{EXAGGERATED IMAGE JUXTAPOSITION}

The poetic approach image juxtaposition, which originated in Chinese poems, is adopted by many western poets who are interested in classical Chinese poetry such as Ezra Pound, Kenneth Rexroth, Gary Snyder and others. Ginsberg is not only familiar with the translated Chinese poems by them, but also experienced the Chinese culture in person. He has read the classics of Chinese Buddhism and the works of Confucius, Lao Tuz, Chuang Tuz, etc. In addition to the poems of $\mathrm{Li} \mathrm{Po}$, Tu Fu, Su Tongpo, Wang Wei and Bai Juyi, the famous poets in the ancient China, he has read the works of modern Chinese poets such as Guo Moruo, Ai Qing, Shu Ting, and Bei Dao as well. Like Rexroth and Snyder, Ginsberg has also learned some Chinese verse skills such as image juxtaposition and employed them in his own poems.

He realized that Pound had achieved amazing effects through his ideogramic method. Fenollosa discovered that Eastern poets juxtaposed two events or observations to imply a relationship or insight which could not be separately stated. In all cases, the juxtaposition involves ellipsis - a pause or space between images in which something not literally shown or said is revealed. According to "Howl", "the alchemy of the use of the ellipse" permits "incarnate gaps in Time \& Space through images juxtaposed" (Forster, 1992, p.103). So Ginsberg said he "tried to keep the language sufficiently dense in one way or another - use of primitive naïve grammar (expelled for crazy), elimination of prosey articles \& syntactical sawdust, juxtaposition of cubist style images, or hot rhythm" (Forster, 1992, p.105). Of various means, perhaps the most important, aside from rhythm, is "the image juxtaposition". But just like his rebellious and innovative personality, he used the skill in an exaggerated way. It is known to all that in classical Chinese poems the poets always juxtapose some peaceful and beautiful images in nature to create mysterious and charming artistic sen ses. But in Ginsberg's poems, he juxtaposes many dirty and ugly images in the modern industrial society to create a kind of density and visual shock so as to arouse reader's antipathy to the modern civilization. The following poem "What the Sea Throws Up at Vlissingen__for Simon Vinkenoog" written on January 3, 1983 serves as a good example of this kind:

Plastic\& cellophane, milk cartons \& yogurt containers, blue \& orange shopping bag nets

Clementine peels, paper sacks, feathers \& kelp, bricks \& sticks,

Succulent green leaves \& pine tips, waterbottles, plywood and tobacco pouches

Coffee jartops, milkbottle caps, rice bags, blue rope, an old brown shoe, an onion skin

Concrete chunks white pebbled, sea biscuits, detergent squeezers, bark and boards, a whisk-brush, a box top

Formula A Dismantling Spray-can, a whole small brown onion, a yellow cup

A boy with two canes walking the shore, a dead gull, a blue running shoe,

A shopping bag handle, lemon half, celery bunch, a cloth net-

Cork bottletop, grapefruit, rubber glove, wet firework tubes,

Masses of iron-brown-tinted seaweed along the high water mark near the sea wall,

A plastic car fender, green helmet broken in half, giant hemp rope knot, tree trunk stripped of bark,

A wooden stake, a bucket, myriad plastic bottles, pasta Zara pack,

A long gray plastic oildrum, bandage roll, glass bottle, tin can, Christmas pine tree

A rusty iron pipe, me and my peepee. (Ginsberg, 2001, p.170-171)

Ginsberg makes a list of all the objects he saw on the shore of Vlissingen. The entire poem just juxtaposes these images in block omitting the conjunctional words, even without any complete sentence or explanation. In this way, the poem leaves much space for readers to fill by their own interpretation. While reading this poem, readers tend to be shocked by the sight of the sea full of garbage created by modern people and realize how seriously the environment is polluted and how evil the people are. Just like Gary Snyder's ecologic poems, the poem can also arouse people's consciousness of environmental protection. Meanwhile, the poem is also permeated with the breath of death. "A boy with two canes walking the shore, a dead gull" shows the damage on human beings and other creatures made by the modern industrial civilization and presents the dying of the conscience and virtue of mankind in a society which is controlled by machines.

In "Howl" the juxtapositions, like the rhythms, are generally violent. Much of the surreal quality of the poem derives from these extreme contrasts, giving it an obvious political force and suggesting regions of awareness that are not open to strict analysis or explanation. Any explanation, of course, deadens the power of the line. The poet must never state, in Ginsberg's words, the "relations themselves, just the images" (Forster, 1992, p.105). The effect is then direct, immediate - emotional as well as conceptual. "It is a visceral approach to poetry," Paul Portuges (1980) has written, "in which the mind rejects its own rational sensibility and undergoes a kind of organic alteration" (p.448).

\section{The TRANSFORMATION FROM “HOWL” TO MEDITATION}

Allen Ginsberg, like Kenneth Rexroth, is an anarchist. He criticizes the politics, the government and the modern industrial civilization with his angry "Howl". For Ginsberg, following Kerouac, the only authority was the authority of the individual. All tyrannies, all ideologies should be swept away by what Ginsberg called "the supernatural extra brilliant intelligent kindness of the soul!" in "Howl”. Louis Ginsberg, Allen's father, earned his living as a high school English teacher, but he was also a poet. Although he was associated with some of the more experimental and innovative writers of his time, his own work was relatively conservative. Ginsberg's early poems were in a traditional style because 
of the influence of his father. But soon after his entrance in Columbia University, he changed to expose the reality and his own thoughts and view on life and politics in his own way because he believes "First thought, best thought." "In Society" written in the spring of 1947 cries out his angry about the society when he first stepped into it:

More company came, including a

Fluffy female who looked like

A princess. She glared at me and

Said immediately: "I don't like you,"

Turned her head away, and refused

To be introduced. I said, "What!"

In outrage. "Why you shit-faced fool!"

This got everybody's attention.

"Why you narcissistic bitch! How

can you decide when you don't even

know me," I continued in a violent

and messianic voice, inspired at

last, dominating the whole room. (Ginsberg, 2001, p.4)

Many of Ginsberg's poems contain a war theme. Subjects such as the Nazi gas chambers and Viet Nam are the topics of many of his poems. In his "Anti-Vietnam War Peace Mobilization" written on May 9, 1970, he also used the skill of image juxtaposition and non-English style sentences to express his antipathy to the war and the government:

White sunshine on sweating skulls

Washington's Monument pyramided high granite clouds

assembled before White House filled with mustached Germans

$\&$ police buttons, army telephones, CIA Buzzers, FBI bugs

Secret Service walkie-talkies, Intercom squawkers to Narco

Fuzz \& Florida Mafia Real Estate Speculators. (Ginsberg, 2001, p.131)

In both Western and Eastern literature history, many poets turn to religion to search for the rest home of spirital when they get old. Ginsberg is no exception and became interested in Buddhism. Buddhism, the ancient and highly philosophical Asian tradition, is the religion of the Beats. It began to influence the lives of the major New York Beat writers in the mid-1950's, Kerouac and Ginsberg began their studies by reading books in libraries, but when they migrated to California they began integrating the religion into their lives, inspired by Gary Snyder and Kenneth Rexroth. In the early 1960s, he went to Eastern countries such as India to visit the famous Buddhist and learn Buddhism. In 1972, he took Buddhism as his religion. When he visited China in 1984, he enjoyed reading the poems by Bai Juyi because he found they had common sentiment in Ch'an Buddhism. Bai Juyi engaged himself with Ch'an and many of his poems contain the spirit and thoughts of Ch'an. “Reading wakas while free, facing incense while meditating. (闲吟四句偈, 静 对一炉香)” is the self-portraiture of Bai Juyi's own meditation of Ch'an. Ginsberg wrote a long poem named "Reading Bai Juyi" in China, which may show his respect to this great ancient Chinese poet. In the latter part this will be discussed further.

Many of Ginsberg's other poems in the late period take as their subject Buddhist Meditation and ideas. "Wichita Vortex Sutra" is a meditation on evil of war in America. Instead of cursing the war and the government, Ginsberg calls for love, calls for the beautiful things. But the war destroys them, so people like Ginsberg thinks in tears about how to speak the right language on the frosty broad road in the time of the war and to stop the evil of the war. The poem goes like this:

we call Love, want and lack--

fear that we aren't the one whose body could be

beloved of all the brides of Kansas City,

kissed all over by every boy of Wichita--

O but how many in their solitude weep aloud like me--

On the bridge over the Republican River

almost in tears to know

how to speak the right language--

on the frosty broad road

uphill between highway embankments

I search for the language

that is also yours--

almost all our language has been taxed by war. (Ginsberg, 2004)

Instead of angry howl, Ginsberg shows his meditation in the poem. His sectary Bob Rosenthal said, while America fell into chaos and outrage due to the Viet Nam war, Ginsberg's poems became meditated and gentle in contrast and became a method of controlling anger and enhancing the understanding of mind and spirit. Ginsberg also expresses his 
rage in "Wichita Vortex Sutra", but unlike in "Howl", he hides the rage behind the calm and rational meditation.

\section{The Poems Written In China}

Allen Ginsberg had yearned towards Chinese culture for a long time. He attempted many times to visit China. But due to the historical reasons in the period and his "notoriety" of homosexual and "mortal corruption", his journey to China was delayed until 1984. He came to this mystic ancient Eastern land eagerly even without his lifelong boyfriend's company, who always companied Ginsberg everywhere but was turned down by the Chinese embassy that time. In the autumn of 1984, Ginsberg visited China as a member of an American writer mission together with Gary Snyder for about two months. And after the other members of the mission went back to America, he stayed in China by himself for some time to have more communication with contemporary Chinese writers and a spiritual dialogue with great ancient Chinese poets. Meanwhile he went to many universities in Beijing, Shanghai, Baoding and Guiling to read and instruct his own poems and other western poets'. He received warm welcome from Chinese readers and students. In the period, he wrote more than ten poems, including "One Morning I Took a Walk in China", "Reading Bai Juyi", "Improvisation in Beijing", "I Love Old Whitman So", "Black Shroud", etc. In these poems Ginsberg depicts his endearment of China and its profound culture. And the poems have been praised as opening a window for western readers to understand China.

"One Morning I Took a Walk in China" records what Ginsberg saw when he was walking on Chinese streets in a morning. The poem draws vivid pictures of the daily life of Chinese people in the early 1980s without any comments. But there is a stream of peaceful thoughts floating under the plain words and common things the words record.

A white headed barber shook out his ragged towel, mirror hung on red nail in the brick wall

Where a student sat, black hair clipped at ears straight across the back of his neck

Soft-formed gritty coal pellets lay drying on the sidewalk and down the factory alley, more

black mats spread,

Long green cabbages heaped by the buildingside waiting for home pot, or stacked on

hand-tractor carts the market verandah a few yards away-

Leeks in a pile, bright orange carrots thick \& rare, green unripe tomatoes, parsley, thin celery

stalks awful cheap, potatoes \& fish-(Ginsberg, 2001, p.184)

Unlike the modern industrial urban life, the peaceful and simple life of Chinese people impressed Ginsberg's deeply and brought him a feeling of great intimacy. The picture of "A white headed barber shook out his ragged towel, mirror hung on red nail in the brick wall" is even hardly to see in China nowadays and can arouse our sweet memory of the simple but intimate early life, let alone a foreign visitor and poet. Maybe he also wants his country's life to return to those old days filled with great ease and little evil. Maybe at the time he remembered one of Bai Juyi's pastoral "Village in Night (村夜)", which unfolds a similar peaceful rural scene before us:

霜草苍苍虫切切, 村南村北行人绝。

独出门前望野田, 月明菾麦花如雪。

(Grass frosty, insects chittering

No passerby seen north or south of the village

Stepping out of home alone, watching the wild field

The bright moonlight, the buckwheat, and its snowy flowers.)

Also, in the poem "One Morning I Took a Walk in China" Ginsberg juxtaposes the common but fresh images such as "long green cabbages", "leeks", "bright orange carrots", "green unripe tomatoes, parsley, thin celery stalks awful cheap, potatoes \& fish", etc., which contain his affection to the life and create a serene artistic sense.

"Reading Bai Juyi" can be regarded as the most important poem among those written by Ginsberg in China. It is a long poem consisting of seven short sub-poems. It records Ginsberg's surgy feeling when he was reading the translated anthology of Bai Juyi poems "in a room with electric heat-A rare commodity in this country" ("Reading Bai Juyi") of a hotel in Shanghai.

As one of Ginsberg's most admired ancient Chinese poets, Bai Juyi (772-846) is one of the most famous poets in middle T'ang Dynasty. He was born in a poor family. Because of offending some dignitaries he was demoted to "Jiangzhou Si Ma" (a lower rank of official title) and sent to a remote area. Influenced by Ch'an poets Han-shan and Wang Fanzhi, who was a representative poet of vulgar poem school in the early period of T'ang Dynasty, his poetry is simple and straightaway with plain words and most of his poems reveal the luxurious life of the dignitaries and show his sympathy to the common people who were experiencing hardship. He believed in Ch'an Buddhism all his life. Many of his poems are permeated with the Buddhist thoughts. When he was demoted to be the governor of Hangzhou he wrote this poem to show his contempt towards earthly praise and insult:

置怀齐宠辱, 委顺随心止。

我自得此心, 于兹十年矣。

(Caring nothing about honor or disgrace

Which goes as it comes

Ten years have gone 
Since the truth I have got.)

When Ginsberg was "Lying head on pillow aching" and "Still reading poems of Tang roads" ("Reading Bai Juyi"), he thought about his own unlucky experience, his antipathy to the administrative government and the vagabond life of the Beat Generation as expressed in the following:

Something Bai said made me press my finger

To my eyes and weep-maybe his love

For an old poet friend, for I also

Have gray on my cheek and bald head (Ginsberg, 2001, p.196)

At the same time, he was also dwelling on the questions about Buddhism and Ch'an meditation - "That So-Chan meditation's frowned on and martial health / Qi-Gong's approved by Marxist theoreticians" — although he didn't believe there was an afterworld after his death:

I don't believe in an afterworld of good or even

another life separate from this incarnation

Still I worry I'll be punished for my carelessness

After I'm dead - my poems scattered and my name

Forgotten and my self reborn a foolish workman

Freezing and breaking rocks on a roadside in Hebei. (Ginsberg, 2001, p.195)

"Since all of earthly trifles are nothing after my death / my poems scattered and my name forgotten / why not spending the life on a boat below a stone bridge for a thousand years like Jiang Ji?" -

...That down the alley

From the stone bridge at Suzhou where Jiang Ji spent

A sleepless night wakened by the bell of Cold Mountain Temple,

Water lapping against his boat a thousand years ago,

A teahouse stands with two-stringed violin and flutes

And wooden stage. (Ginsberg, 2001, p.195)

The eremitic life of the ancient Chinese poets, the boat, the two-stringed violin, the flutes and wooden stage - all of these intensified Ginsberg's affection for Chinese culture, and he even was not willing to go back to his country if there was no compulsory returning because of his homosexuality, which could not be accepted in China at that time.

In the last part of "Reading Bai Juyi”, he imitates Bai Juyi's poem “A Night in Xingyang (《信阳一夜》) to summarize his fifty-eight-years life and express his understanding of life that all things would disappear, only river flows "as they did before":

I grew up in Paterson New Jersey and was

Just a virginal kid when I left

Forty years ago. Now I'm around the world,

But I did go back recently to visit my stepmother.

Then I was 16 years old, now I'm fifty eight-

All the fears I had in those days-I can still see myself

Daydreaming reading N.Y. Times on the Chinese rug on the living room

Floor on Graham avenue. My childhood houses are torn down,

None of my old family lives here any more,

Mother under the ground in Long Island, father underground

Near the border of Newark where he was born.

A highway cuts thru the Fair Street lot where I remember our earliest

Apartment, \& a little girl's first kiss. New buildings rise on that street,

All the old stores along Broadway have disappeared.

Only the Great Falls and the Passaic River flow

Noisy with mist then quietly along brick factory sides

As they did before. (Ginsberg, 2001, p.200-201)

\section{CONCLUSION}

The definition of the Beat Generation in Reader's Digest Illustrated Encyclopedic Dictionary (1987) offers a powerful support to the theme of this paper: "In the 1950's, a group of young Americans, including Jack Kerouac, Allen Ginsberg, and William Burroughs, who expressed disillusionment with Western values and turned for inspiration to Eastern religion, trying experimental literary forms and adopting a bohemian lifestyle" (p.158).

Allen Ginsberg, as well as other poets and writers of the Beat Generation, have found their last home for their anchorless heart in the classical Chinese poems and the Chinese thoughts and philosophy. And through their poems the essence of Chinese culture is also accepted and understood by many other Western people and influences their thoughts and life as well.

\section{REFERENCES}


[1] Allen, Donald M. (ed.) (1960). The New American Poetry. New York: Grove Press.

[2] Foster, Edward H. (1992). Understanding the Beats. Columbia: University of South Carolina Press.

[3] Ginsberg, Allen. "Wichita Vortex Sutra". On-line, Available from http://english.buffalo.edu/faculty/conte/syllabi/377/Allen_Ginsberg.html (accessed 25/11/2004).

[4] Ginsberg, Allen. (2001). Howl-Allen Ginsberg: Selected Poems (1947-1997). Trans. Wen Chu'an. Chengdu: Sichuan Literature \& Art Press.

[5] Hamalian, Linda. (1991). A Life of Kenneth Rexroth. New York: W.W. Norton \& Company.

[6] Hassan, Ihab. (1973). Contemporary American Literature: 1945 1972. New York: Frederick Ungar Publishing Co..

[7] Lodge, David. (1972). 20th Century Literary Criticism. New York: Longman House.

[8] Rodman, Selden. (1946). A New Anthology of Modern Poetry. New York: The Modern Library.

[9] Paul Portuges, "Allen Ginsberg's Paul Cezanne and the Pater Omnipotens Aeterna Deus," Comtemporary Literature 21 (Summer 1980), 448, cited Edward H. Foster, Understanding the Beats, 105.

[10] Waley, Arthur, trans. (1998). Tao Te Ching, by Lao Tuz. Peking: Foreign Language Education \& Research Press.

Min Yu was born in Shuyang City, Jiangsu Province on February 12, 1978. She got the MA of Arts at Southeast University in Nanjing, China in 2005. She is a faculty member of Foreign Language Department in Huaiyin Institute of Technology, China. Her research interests include American Literature and the comparative literature between China and America. 